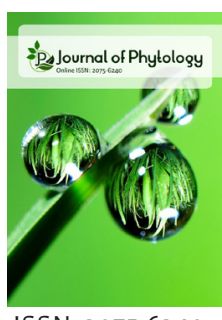

ISSN: $2075-6240$

\title{
Essential oil composition of Origanum vulgare and its application in substitution of synthetic chemical additives
}

\author{
Sonia Heni*, Hicham Boughendjioua', Salima Bennadja², \\ Abdelghani Djahoudi3
}

\begin{abstract}
'Laboratory of Chemistry, Physics and Materials Biology, Higher School of Professors for Technological Education, Skikda, Algeria, 'Laboratory of Vegetable Biology, Department of Pharmacy, Faculty of Medicine, BadjiMokhtar University, Annaba, Algeria, ${ }^{3}$ Laboratory of Microbiology, Department of Pharmacy, Faculty of Medicine, BadjiMokhtar University, Annaba, Algeria
\end{abstract}

\begin{abstract}
In this work, the Gas Chromatography-Mass Spectrometry (GC/MS) analysis of the essential oil of Origanum vulgare L. obtained by hydrodistillation was carried out and it allowed to identify $98.1 \%$ of its constituents. The main components were carvacrol (47.6\%), thymol (16.6\%), p-cymene (13.5\%) and $\gamma$-terpinene (11.2\%). The chemical components of the essence are distributed over five biochemical classes represented mainly by monoterpene phenols and monoterpene carbides. The extraction gave a yield of oil $2.8 \%$. The minimum inhibitory concentration (MIC) of this oil was determined against food spoilage bacteria and pathogenic bacteria belonging to the genus Staphylococcus tested in vitro. This study aims to enhance the value of oregano essential oil by determining its chemical composition, and by its application as a natural antibacterial preservative in substitution of synthetic chemical additives. The sample was incorporated into a sensitive food matrix exposed to bacterial contamination: white meat. The bacteriostatic/bactericidal power of this bioactive extract was determined by a significant reduction in the number of bacteria and a clear increase in shelf life. Thus, it is possible to propose the use of this aromatic essence as a source of natural preservative.
\end{abstract}

Received: May 23, 202

Revised: June 28, 2021

Accepted: July 01, 2021

*Corresponding Author:

Sonia Heni,

E-mail:heni.sonia@yahoo.com

Keywords: Origanum vulgare, essential oil, analytical study, white meat, microbiological analysis, preservative effect.

\section{INTRODUCTION}

One of the main problems of the food industry is to ensure that food products are well preserved, particularly against microbial contamination, which is the most feared. The latter can be caused by various microorganisms such as viruses, yeast parasites, moulds and bacteria. There are two types of contaminating bacteria; spoilage bacteria, that are harmless to the consumer but cause various food spoilage; and potentially pathogenic bacteria, which can cause infection or toxic infections when they produce enterotoxins (Le Loir et al., 2003; Jenny et al., 2011) and even lead to serious infections. The presence of these bacteria in food lead to a reduction in nutritional values through loss of vitamins and modification of organoleptic properties through their proteolytic and lipolytic activity and produce molecules with unpleasant odours through deamination of amino acids, decarboxylation of amino acids and finally degradation of sulphur amino acids, and sometimes even the appearance of toxic substances (Pascal, 1979; Nessrien \& Mohamed, 2007).

Meat is undoubtedly one of the foods most exposed to this scourge. For nutritional reasons, this foodstuff occupies a prime position in the human diet (Clinquart et al., 1999). Its composition in water and proteins of high biological value makes it a very favourable niche for the development of microorganisms that can reach a dangerous threshold (Benaissa, 2014). Therefore, it is the object of increasing concern in modern society. In the past, it was preserved by drying, salting or smoking (Collin, 1972), but to avoid the problem of contamination, it is common practice in the food industry to add synthetic chemicals (Patrone et al., 2010). Whether or not they have a nutritional value and whose intentional addition has a technological or organoleptic purpose, they can become a component of the foodstuff, such as food additives. Synthetic additives include antibacterial preservatives (Nakahara et al., 2003). 
The issue of greatest concern for public health remains the impact of these compounds on the consumer (Burt, 2004) due to their short- and long-term toxic, neurotoxic, mutagenic and even teratogenic effects (Ho et al., 2009; Chahardehi et al., 2010). Several synthetic preservatives have been restricted or banned in several countries. Antibiotics, among them, occupy a significant place as preservatives against food spoilage. Developing countries are the most sensitive to this problem, suffering enormous damage, leading to immeasurable economic losses and major health risks (Ownagh et al., 2010). This has prompted the search for alternative solutions to combat resistant bacteria, through the search for new antibacterials such as bacteriophages, peptides and plants.

Currently, the focus is on aromatic and medicinal plant extracts such as essential oils, which are experiencing renewed interest. Although these essential oils are mostly toxic, many authors(Rota et al., 2008; Kempf et al., 2011; Amrouni et al., 2014; Atailia et al., 2015; Heni et al., 2015a; Heni et al., $2015 b)$ report an antibacterial effect. They contribute to the improvement of taste qualities, and are classified as "Generally Recognized AsSafe" (GRAS) and approved for food use by the US Food and Drug Administration (Lis-Balchin, 2004; Caillet et al., 2007; Buronzo, 2008). Among the aromatic and medicinal plants is oregano, which is a spontaneous and abundant plant in north-eastern Algeria. It is part of the Algerian culinary heritage and is used fresh or dried as a spice in certain meat dishes, both for its preservative qualities and its savoury taste. It is also used in the control of microorganisms, which could reduce the risk of spoilage and ensure food safety for consumers. Moreover, this plant is an important source of bioactive molecules (Bruneton, 2008). Among these substances, essential oils with a complex chemical composition and rich in active compounds, act on various cellular targets; this contributes to the resolution of the issue of bacterial resistance.

A chemical screening of the extracted oil was carried out and this study aims to highlight its probable antibacterial activity through its use as a preservative for a sensitive foodstuff of essential nutritional value: white meat. The results of the experiments allowed to calculate the bacterial reduction capacity in this foodstuff and to study its activity over time.

\section{MATERIALS AND METHODS}

\section{Plant Material and Essential Oil Extraction}

The aerial parts of Origanum vulgare, were collected from the region of Hammadi Krouma (Skikda, North-East, Algeria). The plant was identified by Dr. Hicham Boughendjioua at the Department of Natural Sciences, Higher School of Professors for Technological Education, Skikda, Algeria. The voucher specimen (Boughendjioua 01/PPL/2020) under the plant's name was deposited in the herbarium.

The essential oil (EO) of the aerial parts of Origanum vulgare L. was obtained by hydrodistylation using a Clevenger type apparatus. An analytical study was carried out to evaluate the quality and chemical composition of the studied oil, first by determining the physicochemical properties. The identification of the chemical composition was carried out by Gas Chromatography-Mass Spectrometry (GC-MS). This allows the identification of the constituents through their molecular mass, depending on the operating conditions.

\section{The Use of Essential Oil as an Antibacterial Substitute for Food Additives}

The effectiveness of the essential oil tested is evaluated by measuring two concentrations: the Minimum Inhibitory Concentration (MIC) and the Minimum Bactericidal Concentration (MBC). These concentrations allow to know the nature of the antimicrobial activity of the essential oil: bacteriostatic or bactericidal. In general, essential oils have quite strong and powerful odours, which may be a limiting factor for their application in foodstuffs. However, undesirable organoleptic effects can be limited by careful selection of the EO according to the type of food being considered (Burt, 2004). On the other hand, the values of the minimum inhibitory concentrations (MICs) obtained in vitro should be affected by a correction coefficient ranging from 2 to 100 , so that they have the same effect in a food matrix (Burt, 2004). For this reason, it is necessary to determine the MIC of the $\mathrm{EO}$, capable of inhibiting bacterial growth without altering the organoleptic characteristics of the food, namely taste and odour.

\section{Analysis}

\section{Sensory analysis}

The sensory analysis was carried out with a panel of ten people on white meat with the extract tested added. The scoring tests were carried out on taste and smell after cooking. After the taste test was performed and the taste was found to be good and the smell unnoticeable, we were able to determine the MIC of EO added to the meat. This is why prior tasting tests in this kind of work are indispensable. Therefore, we found it useful to multiply the MIC value by a correction factor of 4 .

\section{Microbiological Analysis of Test Samples}

White meat samples (chicken steak) were spiked with $0.1 \%$ Origanum vulgare EO and stored at $4^{\circ} \mathrm{C}$ for $48 \mathrm{~h}$. To determine the bacterial burden at different storage times (0 min- $40 \mathrm{~min}-24 \mathrm{~h}$ and $48 \mathrm{~h}$ ), the same protocol was followed for control samples (no EO added) under the same conditions.

\section{Quantitative Analysis}

Contamination microflora (total aerobic mesophilic flora) was studied by the Colorimetry method in liquid medium (most probable number, MPN), for both samples, with EO and the control sample; during the different storage times from $0 \mathrm{~min}$ to $48 \mathrm{~h}$. The inoculation was carried out from dilutions $\left(10^{-1}\right.$, $10^{-2}$ and $10^{-3}$ ) and we introduced $1 \mathrm{ml}$ of the inoculum into 
tubes containing $7 \mathrm{ml}$ of nutrient broth (a series of 4 tubes for each dilution). The tubes were well homogenised with a shaker. Incubation of the seeded sets of tubes was done at $37^{\circ} \mathrm{C}$ for $24 \mathrm{~h}$. Tubes showing cloudiness of the nutrient broth medium were considered positive. The final reading, as well as the bacterial count by the MPN test, was performed according to the Mac Grady table. Each inoculation was performed in triplicate.

Pathogenic microorganisms (Staphylococcus aureus) studied by inoculating Petri dishescontaining Chapman's selective medium with $0.1 \mathrm{ml}$ of the dilution $\left(10^{-1}\right)$ on the surface using a raking pipette. The seeded dishes were then incubated at $37^{\circ} \mathrm{C}$ for 24-48 h. Staphylococcus aureus is pigmented yellow, surrounded by a clear halo. Non-pathogenic staphylococci are characterized by transparent, slimy colonies. The number of Staphylococcus aureus was determined in Colony-Forming Units (CFU/g) of the sample. Each inoculation was performed in triplicate.

\section{Calculate the Bacterial Reduction Capacity}

We calculated the bacterial reduction capacity of the tested extract and thus studied its activity over time. This reduction capacity considered by this study is the difference between the number of bacteria sought in meat without extract and that sought in meat with added oil, for the contamination flora and $S$. aureus enumerated during the different conservation times. The capacity to reduce the bacterial load is expressed as a percentage and is calculated according to the following formula:

\section{Reduction capacity $=[(\mathrm{NA}-\mathrm{N}) / \mathrm{NA}] \times 100$}

where, NA is the number of bacteria calculated in the nonadded meat and $\mathrm{N}$ is the number of bacteria calculated in the added meat.

\section{Statistical Analysis of Results}

The results were analysed by calculating the means plus or minus the mean standard deviation. They are compared to the control by Student's t-test (STATISTICA 8). The confidence level is $95.00 \%$ and the difference between the means is considered: very highly significant if $\mathrm{p} \leq 0.01$, highly significant if $\mathrm{p}$ is between 0.01 and 0.1 ; there is no significant difference if $\mathrm{p} \geq 0.5$.

\section{RESULTS AND DISCUSSION}

\section{Analytical Study of the Essential oil of Origunam vulgare}

Table 1. Physico-chemical parameters of Origunam vulgare essential oil

\begin{tabular}{lcc}
\hline Physico-chemical parameters & Origanumvulgare & AFNOR standards \\
\hline Relative density & 0,920 & {$[0,894-0,930]$} \\
Refractive index & 1,4920 & {$[1,4830-1,510]$} \\
Miscibility in ethanol & $(2 \mathrm{v} / 1 \mathrm{v})$ & {$[2 \mathrm{v} / 1 \mathrm{v} / 3 \mathrm{v} / 1 \mathrm{v}]$} \\
Acid index & 4,9 & {$[4,1-5,2]$} \\
Ester index & 51,98 & {$[49,5-52,55]$} \\
\hline
\end{tabular}

The yield of extracted oil was $2.8 \%$ and it is an important source of bioactive molecules. Table 1 shows that the physico-chemical parameters the essential oil it is a quality that meets AFNOR (2000) standards and is relatively pure.

\section{Chemical Composition}

Chemical composition analysis (Figurel) showed a wide range of compounds. The essential oil is composed of 25 compounds that represent about $98.1 \%$ of the total oil (Table 2). The oil consists mainly of Carvacrol (47.6\%) followed by Thymol (16.6\%),p-cymene(13.5\%) and $\gamma$-terpinene (11.2\%).

The constituents of the essential oil are divided into five biochemical classes represented mainly by monoterpene phenols and monoterpene carbides (Figure 1).

Table 2. Chemical composition of Origunam vulgare essential oil

\begin{tabular}{|c|c|c|c|}
\hline Peak No. & Retention time (Rt) & Compounds & $\%$ \\
\hline 01 & 2.99 & $\alpha$-thujene & 0.3 \\
\hline 02 & 5.42 & $\alpha$-pinene & 0.7 \\
\hline 03 & 5.64 & Camphène & 2.1 \\
\hline 04 & 6.02 & Octen-3-ol & 0.1 \\
\hline 05 & 6.75 & 3-Octanone & 0.2 \\
\hline 06 & 6.94 & $\beta$-pinene & 0.2 \\
\hline 07 & 7.01 & $\beta$-Myrcène & 0.3 \\
\hline 08 & 7.48 & $\alpha$-phellandren & 0.2 \\
\hline 09 & 7.79 & $\alpha$ - terpinene & 1.6 \\
\hline 10 & 8.11 & p-cymene & 13.5 \\
\hline 11 & 8.18 & $\beta$-phellandren & 0.2 \\
\hline 12 & 8.24 & Limonène & 0.3 \\
\hline 13 & 8.30 & 3-p-Menthanone & 0.6 \\
\hline 14 & 9.07 & $\gamma$-terpinene & 11.2 \\
\hline 15 & 10.36 & Cis- $\beta$-Ocimene & 0.3 \\
\hline 16 & 10.48 & Terpinolène & 0.2 \\
\hline 17 & 13.08 & Linalool & 0.3 \\
\hline 18 & 14.50 & Bornéol & 0.2 \\
\hline 19 & 16.15 & Terpinen-4-ol & 0.4 \\
\hline 20 & 17.29 & Carvacrol & 47.6 \\
\hline 21 & 17.51 & Thymol & 16.6 \\
\hline 22 & 21.73 & $\alpha$-Terpeneol & 0.3 \\
\hline 23 & 22.61 & $\beta$-Caryophylene & 0.2 \\
\hline 24 & 23.79 & $\beta$-Bisabolène & 0.3 \\
\hline 25 & 24.51 & Sesquiphellandrene & 0.2 \\
\hline Total & & & 98.1 \\
\hline
\end{tabular}

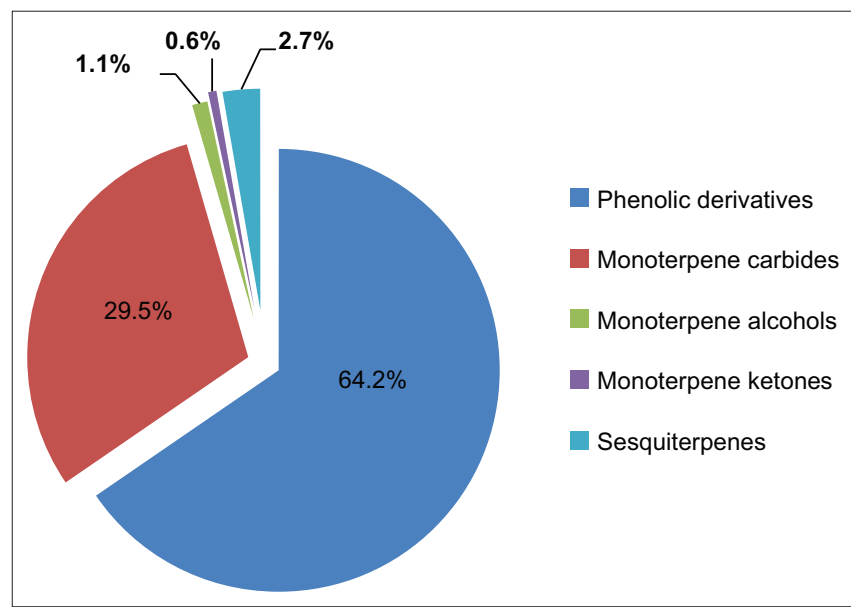

Figure 1:Biochemical classes of Origunamvulgare essential oil 


\section{Microbiological analysis}

Enumeration of total aerobic mesophilic flora and staphylococcus aureus

Quantitative analysis showed that from the first hours of storage, the oil allowed a reduction in bacterial numbers, whereas in the other specimens without EO, there was an increase in the latter. This shows that the effect of the EO is instantaneous, it progresses in time and is maintained up to $48 \mathrm{~h}$ of storage at $4^{\circ} \mathrm{C}$. The results in the form of averages are grouped in (Table 3). The addition of the essential oil shows an immediate bacteriostatic inhibition, with a slight reduction of the bacterial load of the contaminating flora and of Staphylococcus aureus. In fact, the inhibiting effect of the oil is maintained after 40 minutes of conservation at $4^{\circ} \mathrm{C}$, with a decrease in the number of bacteria for the total aerobic mesophilic flora and a remarkable decrease on the Chapman medium. This again shows the antimicrobial power of the tested extract. This effect is maintained at an acceptable level despite the storage time and temperature.

Table 3. Variation of the bacterial load at different storage times

\begin{tabular}{|c|c|c|c|c|}
\hline \multirow[t]{3}{*}{ Time } & \multicolumn{4}{|c|}{ Bacterial physiological groups } \\
\hline & \multicolumn{2}{|c|}{ Control sample } & \multicolumn{2}{|c|}{ Sample added with E0 } \\
\hline & $\begin{array}{l}\text { Bacterial load of } \\
\text { total aerobic } \\
\text { mesophilic } \\
\text { flora (CFU/g) }\end{array}$ & $\begin{array}{l}\text { Bacterial } \\
\text { load of } \\
\text { S. aureus } \\
(\text { CFU } / g)\end{array}$ & $\begin{array}{l}\text { Bacterial load of } \\
\text { total aerobic } \\
\text { mesophilic } \\
\text { flora (CFU/g) }\end{array}$ & $\begin{array}{l}\text { Bacterial } \\
\text { load of } \\
\text { S. aureus } \\
\text { (CFU/g) }\end{array}$ \\
\hline$\overline{T_{1}}$ & $\begin{array}{c}8.2 \times 10^{2} \pm \\
0.033\end{array}$ & $\begin{array}{c}1.1 \times 10^{3} \pm \\
0.02\end{array}$ & $\begin{array}{c}9.9 \times 10^{2} \pm \\
0.06\end{array}$ & $\begin{array}{c}2.1 \times 10^{3} \pm \\
0.08\end{array}$ \\
\hline $\mathrm{T}_{2}$ & $\begin{array}{c}7.5 \times 10^{2} \pm \\
0.02\end{array}$ & $\begin{array}{c}5.8 \times 10^{2} \pm \\
0.01\end{array}$ & $\begin{array}{c}1.13 \times 10^{3} \pm \\
0.04\end{array}$ & $\begin{array}{c}3.6 \times 10^{3} \pm \\
0.05\end{array}$ \\
\hline $\mathrm{T}_{3}$ & $\begin{array}{c}6.1 \times 10^{2} \pm \\
0.002\end{array}$ & $\begin{array}{c}4.2 \times 10^{2} \pm \\
0.001\end{array}$ & $\begin{array}{c}2.5 \times 10^{3} \pm \\
0.01\end{array}$ & $\begin{array}{c}5.8 \times 10^{3} \pm \\
0.02\end{array}$ \\
\hline $\mathrm{T}_{4}$ & $\begin{array}{c}2.4 \times 10^{2} \pm \\
0.001\end{array}$ & $\begin{array}{c}3 \times 10^{2} \pm \\
0.002\end{array}$ & $\begin{array}{c}3.1 \times 10^{3} \pm \\
0.02\end{array}$ & $\begin{array}{c}6.2 \times 10^{3} \pm \\
0.04\end{array}$ \\
\hline
\end{tabular}

The inhibitory effect of the EO was maintained after $24 \mathrm{~h}$ of storage as well, and the bacterial count became significant for the sample without the essence and reached its maximum for both bacterial physiological groups. The addition of the additive to the sample resulted in an accentuated reduction of the bacterial load for the total aerobic mesophilic flora and significant for $S$. aureus. For the unsupplemented sample, and after $48 \mathrm{~h}$ of conservation under the same conditions, the bacterial load is greater for the total aerobic mesophilic flora and reaches its maximum for $S$. aureus. For the sample enriched with $\mathrm{EO}$, the reduction of the bacterial load is highly significant compared to the control sample, without additive.

\section{Bacterial Load Reduction Capacity}

The reduction capacity considered by this study is the difference between the bacterial load of the total aerobic mesophilic flora and S. aureus in the sample without essential oil and the one enriched with extract, from the results obtained, it appears that the tested oil showed a reduction rate ranging from $17.17 \%$ to $92.25 \%$ for the total aerobic mesophilic flora and much higher for S. aureus, $52.38 \%$ to $95.18 \%$ (Figure 2 and Figure 3). It is evident from our results that the application of Origanum vulgare EO at a low concentration that did not alter the organoleptic characteristics of the food matrix (according to the taste test), allowed a reduction of the bacterial load for the different storage times, compared to the control sample.

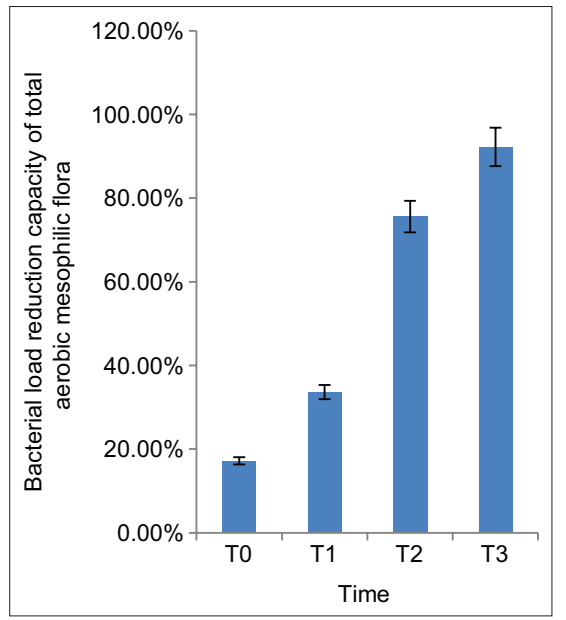

Figure 2: Bacterial load reduction capacity of total aerobic mesophilic flora

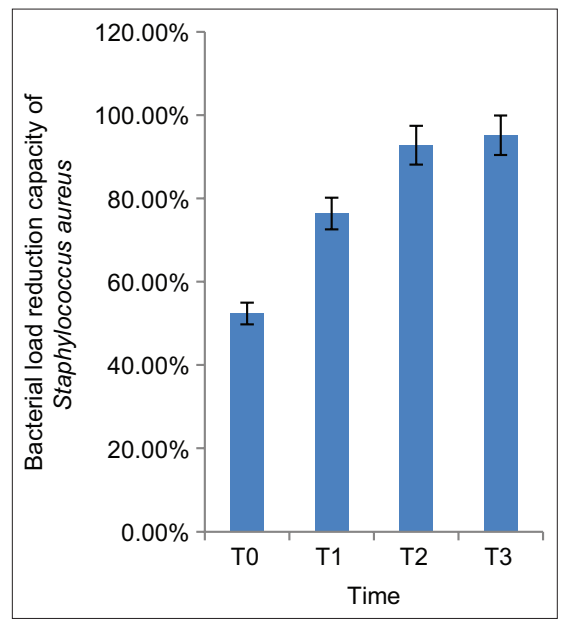

Figure 3: Bacterial load reduction capacity of Staphylococcus aureus

It turns out that the inhibitory effect of this bioactive extract is instantaneous, it progresses in time and is maintained until $48 \mathrm{~h}$ of conservation at $4^{\circ} \mathrm{C}$, allowing a significant reduction $(0.1<\mathrm{p}<0.01)$ of the sought bacterial load and very highly significant $(p \leq 0.01)$ of that of $S$. aureus, according to the statistical analysis. From this, in the presence of EO and from 40 min until $48 \mathrm{~h}$ of conservation, the number of $S$. aureus reached a value almost zero. These results are confirmed by another study conducted on red meat (Heni et al., 2020). This explains that Oregano EO has a very strong anti-staphylococcal activity once it is in contact with the target bacteria (bactericidal effect).

The progress of the inhibitory effect of oil could be due to the storage conditions $\left(4^{\circ} \mathrm{C}\right)$. However, the availability of nutrients in the meat such as fats, proteins; antioxidants, salt and other substances, as well as $\mathrm{pH}$, temperature, type of packaging 
and characteristics of the microorganism, can undoubtedly influence the activity of EO. For example, according to Holley and Patel (2005), at low $\mathrm{pH}$, the hydrophobicity of some EOs increases, allowing them to dissolve easily in the lipid phase of the bacterial membrane.

Burt (2004) suggested that low water content in food may hinder the action of antimicrobial agents towards target sites in the bacterial cell. Thus, the high level of water and salt would facilitate the action of EOs in meat products. By forming a protective layer of fat around the bacteria or the lipid fraction in the food may absorb the antimicrobial agent by decreasing its concentration and efficacy in the water phase. The fact that Oregano EO is among the most suitable for application in meat and meat products (Caillet and Lacroix, 2007) and the specificity of its antibacterial activity. This study affirms the renewed interest in essential oils, which successfully demonstrates their potential use to reduce or control pathogenic flora in food products as an alternative to chemical additives.

It should be noted that our bioactive extract, rich in phenolic derivatives, is very active; a situation reported by Burt in his comparative study based on the content of oils (Burt, 2004). This activity is attributed to Carvacrol and Thymol (Kempf et al., 2011). Thymol, being their major component, binds to membrane proteins and increases permeability, destabilizing cell integrity. It also interferes with the synthesis of structural components (Trombetta et al., 2005) and energy metabolism leading to cell death (Ultee et al., 2002; Nguefack et al., 2004; Cristani et al., 2007). Carvacrol, thus present, accentuates this effect by inhibiting ATPase activity (Gill \& Holley, 2006), without neglecting the activity linked to monoterpene hydrocarbons, notably pcymene and $\gamma$-terpinene, which are present in sufficient quantities in our oil. These are precursors of carvacrol biosynthesis. They facilitate its intracellular penetration thus potentiating its action (Ultee et al., 2002).

The progress of the inhibitory effect of oil could be due to the storage conditions $\left(4^{\circ} \mathrm{C}\right)$. However, the availability of nutrients in the meat such as fats, proteins; antioxidants, salt and other substances, as well as $\mathrm{pH}$, temperature, type of packaging and characteristics of the microorganism, can undoubtedly influence the activity of EO. For example, according to Holley and Patel (2005), at low $\mathrm{pH}$, the hydrophobicity of some EOs increases, allowing them to dissolve easily in the lipid phase of the bacterial membrane.

In addition, a strong affinity for cytoplasmic membranes can disrupt and affect by causing their swelling to a greater extent than carvacrol (Burt, 2004). The antibacterial activity of essential oils can also be attributed to the phenomenon of synergy between all the volatile constituents; the synergistic interactions between the different compounds can be at the origin of a much more pronounced activity than that predicted for the majority of compounds(Lahlou et al., 2004). The antibacterial activity depends on the chemical composition of the EOs and is related to the bacterial physiological groups.

\section{CONCLUSIONS}

The essential oil of Origanum vulgare is highly appreciated in terms of taste, and its addition to white meat showed an immediate bacteriostatic inhibiting effect with a lytic power beyond forty minutes. Thus, a highly significant reduction capacity of the total aerobic mesophilic flora and very highly significant of Staphylococcus aureus was recorded. This inhibitory effect progresses over time and is maintained up to 48 hours of storage at $4^{\circ} \mathrm{C}$. The reduction power is such that it is almost total for staphylococci after 48h. This explains why the essential oil of Oregano has a bactericidal effect on Staphylococcus aureus, confirming the results obtained in vitro. The present study suggests the use of this type of bioactive molecule in foodstuffs as a substitute for the usual chemical additives, which opens up the prospect of its use in preventing and combating the deterioration of preserved food products. In addition to its economic impact, this oil would contribute to the fight against food poisoning and multi-resistant bacteria.

\section{REFERENCES}

AFNOR NF T 75-006. (2000). Association Française de Normalisation Recueil de Normes Française "Huiles essentielles". AFNOR, Paris.

Amrouni, S., Touati, M., Hadef, Y., \& Djahoudi, A. G. (2014).Effet de I'huile essentielle d'Origanumvulgareet de Thymus ciliatussur Pseudomonas aeruginosa VIM-2 carbapénèmase. Phytothérapie, 12, 125-127. https://doi.org/10.1007/s10298-014-0842

Atailia, I., \& Djahoudi, A. G. (2015).Composition chimique et activité antibactérienne de l'huile essentielle de Géranium rosat (Pelargonium graveolens (L’Hér.) cultivé en Algérie. Phytothérapie.13:156- 162. https://doi.org/10.1007/s10298-015-0950-2

Benaissa, A., Ould El HadjKhelil, A., Adamou, A., Babelhadj, B., Hammoudi M. \& Riad, A. (2014). Qualité de la viande de dromadaire dans les abattoirs de Ouargla en Algérie. Contamination bactérienne superficielle des carcasses. Revue d'élevage et de médecine vétérinaire des pays tropicaux. 232. https://doi.org/10.19182/ remvt-20565

Bruneton, J. (2008). Pharmacognosie, phytochimie, plantes médicinales, 2ème édition, Paris, Tec \& Doc- Editions médicales internationales. p. 1188.

Buronzo, A. M. (2008). Grand guide des huiles essentielles. Ed. Hachette pratique.p. 191.

Burt, S. (2004). Essential oils: their antibacterial properties and potential applications in foods-a review. International Journal of Food Microbiology, 94, 223-253. https://doi.org/10.1016/jijfoodmicro-2004-03-022

Caillet, S., \& Lacroix, M. (2007).Les huiles essentielles: Leurs propriétés antimicrobiennes et leurs applications potentielles en alimentaires. Laboratoire de Recherche en Science Appliquées à l'Alimentation (RESALA) de I'INRS-Institut Armand Frappier, Université de Laval (Québec).

Chahardehi, A. M., Ibrahim, D., \& Sulaiman, S. F. (2010). Antioxidant, antimicrobial activity and toxicity test of pileamicrophylla. International Journal of Microbiology, 6, 826- 830. https://doi. org/10.1155/2010-826830

Chelin, J., Wallin-Carlquist, N., Cohn, M. T., Lindqvist, R., Barker, G. C., \& Rådström, P. (2011). The formation of Staphylococcus aureus enterotoxin in food environments and advances in risk assessment. Virulence, 2(6), 580-592. https://doi.org/10.4161/ viru.2.6.18122

Clinquart, A., Fabry, J., \& Casteels, M. (1999). Chapitre: La viande et les produits de viande dans notre alimentation. Edition du CNRS. p.76.

Collin, D. (1972). La viande de bovins. Livre I. Tome III Doin. p.121.

Cristani, M., D'Arrigo, M., \& Mandalari, G. (2005). Interaction of four monoterpenes contained in essential oils with model membranes: implications for their antibacterial activity. Journal of Agricultural and Food Chemistry, 55(15), 6300-6308. https://doi.org/10.1021/fjf070094 
Gill, A.O., \& Holley, R. A. (2006). Inhibition of membrane bound ATPases of Escherichia coli and Listeria monocytogenes by plant oil aromatics. International Journal of Food Microbiology, 111, 361-379. https://doi. org/10.1016/j-ijfoodmicro2006-04-046

Heni, S., Abdesselam, A., Kermiche, F., Bennadja, S., \& Djahoudi, A. (2015). Sensibility of Methicillin Resistant Staphylococcus aureus to Essential Oil of Thymus ciliatus. International Journal of Pharmaceutical Sciences Review and Research, 35(2), 263-267.

Heni, S., Bennadja, S., \& Djahoudi, A. (2015).Chemical composition and antibacterial activity of the essential oil of Thymus ciliatus growing wild in North Eastern Algeria. Journal of Applied Pharmaceutical Science, 5(12), 056-060. https://doi.org/10.7324/2FJAPS-2015-501209

Heni, S., Boughendjioua, H., Meliani, S., Bennadja, S., \& Djahoudi, A. (2020). Use of Origanum vulgare essential oil as an antibacterial additive in the preservation of minced meat. Journal of Pharmaceutical Research International, 32, 1-9. https://doi.org/10.9734/jpri2020-v32-i3230927

Ho, C. L., Wang, E. I. C., \& Su, Y. C. (2009). Essential oil compositions and bioactivities of the various parts of Cinnamomum camphora Sieb. var. linaloolifera Fujuta. Forest Research Quarterly, 31(2), 77-96. https:// doi.org/10.29898/SHBO.200906.0006

Holley, R.A., \& Patel, D. (2005). Improvement of shelf-life and safety of perisable foods by plant essential oils and smoke antimicrobials. Food Microbiology, 22, 273-292. https://doi.org/10.1007/j.fm2004-08-006

Kempf, M., Eveillard, M., Kowalczyk, F., Rossines, E., Panhelleux, G., \& JolyGuillou, M. L. (2011). Antibacterial activity against 224 clinical bacterial strains of JCA 250 and JCA 251 compounds containing essential oils provided from Aroma Technologies research. Pathologie Biologie, 59, 39-43. https://doi.org/10.1016/j.patbio-2010-08-001

Lahlou, M. (2004). Methods to study phytochemistry and bioactivity of essential oils. Phytotherapy Research, 18(6), 435- 448. https://doi. org/10.1002/ptr-1465

Le Loir, Y., Baron, F., \& Gautier, M. (2003). Staphylococcus aureus and food poisoning. Genetics and molecular research, 2, 63-76.

Lis-Balchin, M. T. (2004). Handbook of herbs and spices. Ed. K.V. Pete (Eds.), (Vol.2), South Bank University, Royaume-Uni.

Nakahara, K., Alzoreky, N. S., Yoshihashi, T., Nguyen, H. T. T., \& Trakoontivakorn, G. (2003). Chemical composition and antifungal activity of essential oil from Cymbopogon nardus (Citronella Grass). Japan Agricultural Research Quarterly, 37(4), 249-252.

Nessrien, M. N. Y., \& Mohamed, A. T. (2007). Antioxidant and antimicrobial effects of marjoram and thyme in coated refrigerated semi fried mullet fish fillets. World Journal of Dairy and Food Sciences, 2(1), 01-09.

Nguefack, J., Budde, B. B., \& Jakobsen, M. (2004).Five essential oils from aromatic plants of Cameroon: their antibacterial activity and ability to permeabilize the cytoplasmic membrane of Listeria innocua examined by flow cytometry. Letters in Applied Microbiology,39, 395-400. https://doi.org/10.1111/j1472-765x-2004-01587

Ownagh, A., Hasani, A., Mardani, K., \& Ebrahimzadeh, S. (2010). Antifungal effects of thyme, agastache and satureja essential oils on Aspergillus fumigatus, Aspergillus flavus and Fusarium solani. Veterinary Research Forum, 1(2), 99-105.

Pascal, G. (1979). Les antioxygènes alimentaires. Cahier de Nutrition et de Diététique, 14, 271-290.

Patrone, V., Campana, R., Vittoria, E., \& Baffone, W. (2010). In Vitro synergistic activities of essential oils and surfactants in combination with cosmetic preservatives against Pseudomonas aeruginosa and Staphylococcus aureus. Current Microbiology, 60(4), 237-241. https:// doi.org/10.1007/s00284-009-9531-7

Rota, M. C., Herrera, A., Martinez, R. M., Sotomayor, J. A., \& Jordàn, M. J. (2008). Antimicrobial activity and chemical composition of Thymus hyemalis essential oils. Food Control, 19, 681-687.

Trombetta, D., Castelli, F., Sarpietro, M. G., Venuti, V., Cristani, M., Daniele, C., Saija, A., Mazzanti, G., \& Bisignano, G. (2005). Mechanisms of antibacterial action of three monoterpenes. Antimicrobial Agents and Ahemotherapy, 49(6), 2474-2478. https://doi.org/10.1128/ AAC.49.6.2474-2478.2005

Ultee, A., Bennik, M. H. J., \& Moezelaar, R. (2002). The phenolic hydroxyl group of Carvacrol is essential for action against the food-borne pathogen Bacillus cereus. Applied and Environmental Microbiology, 68, 1561-1568. https://doi.org/10.1128/aem68-4-1568-2002

Ultree, A., Slump, R. A., Steging, G., \& Smid, E. J. (2002). Antimicrobial activity of carvacrol on rice. Journal of Food Protection, 63, 620-624. https://doi.org/10.4315/0362-028x-63-5-620 